\title{
PROSES MENJADI TANGGUH BAGI IBU YANG MEMILIKI ANAK DENGAN GANGGUAN SPEKTRUM AUTIS
}

\author{
Nurussakinah Daulay ${ }^{1}$, Neila Ramdhani ${ }^{2}$, Noor Rochman Hadjam ${ }^{3}$ \\ ${ }^{1}$ Fakultas Ilmu Trabiyah dan Keguruan, Universitas Islam Negeri Sumatera Utara \\ Jalan William Iskandar Pasar 5 Medan Sumatra Utara, 20371 \\ ${ }^{2,3}$ Fakultas Psikologi, Universitas Gadjah Mada \\ Jalan Sosio Humaniora Bulaksumur Yogyakarta, 55281 \\ 11 nurussakinah@uinsu.ac.id, ${ }^{2}$ neila_psi@ugm.ac.id, ${ }^{3}$ nrochman@ugm.ac.id
}

\begin{abstract}
The deficiencies of children with autism cause various difficulties resulting in maternal stress. Therefore, the ability of mothers to manage stress as the reflection of the functioning of self and hardiness personality is needed. The purpose of this study was to examine the experiences which could emerge hardiness personality in caring children with autism spectrum disorders. This research used phenomenology approach and involved five respondents selected by purposive sampling technique. The results show six themes demonstrating the experience of mother-caring children with autism spectrum disorder. The themes were: 1) difficulty, pressing, and surviving conditions; 2) social support; 3) appropriate knowledge and information related to caring children with autism; 4) religious coping; 5) the meaningfulness of life by having children with special need; 6) optimism. In conclusion, internal resources such as the ability of mother to control themselves, sense of competence, and religious coping, then external resources such as perceived social support, are the main factors influencing mother to remain in parenting.
\end{abstract}

Keywords: autism spectrum, hardiness, optimism, perceived social support, religious coping.

\begin{abstract}
Abstrak
Keterbatasan-keterbatasan yang dialami anak dengan gangguan spektrum autis dapat menimbulkan berbagai kesulitan hingga dibutuhkan ketangguhan ibu dalam menjalankan pengasuhan. Tujuan penelitian ini adalah untuk mengkaji pengalaman ibu hingga menjadi sosok yang tangguh selama mengasuh anak autis. Penelitian ini menggunakan pendekatan fenomenologi dan melibatkan lima orang responden penelitian. Hasil penelitian menemukan enam tema pengalaman ibu yang menjadikan mereka tangguh dalam mengasuh anak dengan gangguan spektrum autis, yaitu: 1) kondisi sulit, menekan, dan bertahan; 2) dukungan sosial; 3) pengetahuan dan informasi terkait anak dengan gangguan spektrum autis; 4) religius coping; 5) kebermaknaan hidup orang tua anak dengan anak berkebutuhan khusus; 6) optimisme. Sumber daya penentu berasal baik dari internal yaitu kemampuan mengontrol diri, keyakinan akan kemampuan diri, dan religious coping, maupun eksternal yaitu dukungan sosial,
\end{abstract}


merupakan faktor utama yang memengaruhi ibu untuk tetap bertahan dalam mengasuh anak.

Kata kunci: dukungan sosial, koping religius, optimis, spektrum autis, tangguh.

\section{Pendahuluan}

Gangguan spektrum autis (selanjutnya ditulis GSA) adalah gangguan perkembangan komplek yang disebabkan adanya gangguan neurologis yang memengaruhi fungsi otak. GSA ditandai dengan penurunan kemampuan bahasa dan komunikasi, interaksi sosial dan bermain, keterbatasan kemampuan imajinasi, perhatian serta minat. Dalam hal perilaku, anak dengan GSA memperlihatkan perilaku yang menonjol yaitu sangat suka melakukan perilaku berulang (American Psychiatric Association, 2013).

Kondisi perkembangan anak dengan GSA ini membuat orang tua merasa menanggung beban berat (Li-Ching, Harrington, Louie, \& Newschaffer, 2008), ditambah sumber daya informasi mengenai penyebab, pengobatan, maupun pengasuhan anak dengan GSA masih sangat terbatas. Kondisi tidak menentu tersebut dapat menjadi sumber stres psikologi orang tua. Beberapa penelitian membuktikan bahwa tingkat stres orang tua yang memiliki anak dengan GSA lebih tinggi dibandingkan dengan tingkat stres pada orang tua yang memiliki anak normal atau anak dengan gangguan perkembangan lainnya (Benson \& Kersh, 2011; McConnell, Savage, \& Breitkreuz, 2014; McStay, Trembath, \& Dissanayake, 2014; Pastor-Cerezuela, Fernández-andrés, Tárraga-mínguez, \& Navarro-peña, 2015; Quintero \& McIntyre, 2010; Samadi, McConkey, \& Bunting, 2014; Serrata, 2012; Weiss, Macmullin, \& Lunsky, 2015; Zablotsky, Bradshaw, \& Stuart, 2013; Zaidman-Zait et al., 2014).

Stres pengasuhan yang dialami orangtua dapat berdampak negatif, baik pada orang tua maupun pada anak. Pada orang tua, stres dapat menyebabkan permasalahan psikologis seperti munculnya psikopatologi dan depresi (Bromley, Hare, Davison, \& Emerson, 2004). Ibu yang mengalami stres dilaporkan memiliki kualitas interaksi yang rendah dengan anak-anaknya (Doussard-Roosevelt, Joe, Bazhenova, \& Porges, 2003), hubungan yang kurang baik di dalam keluarga (Rao \& Beidel, 2009), dan ketidakpuasan di dalam perkawinan (Gau et al., 2012; Navot, Jorgenson, Stoep, Toth, \& Webb, 2015). Pada anak dengan GSA, stres yang dialami orang tua dapat memicu penurunan perkembangan (Pruitt, Willis, Timmons, \& Ekas, 2016) yang berdampak kepada memburuknya karakter dan kompetensi anak (Baumrind \& Thompson, 2002).

Besarnya pengaruh stres pengasuhan ini menimbulkan pertanyaan bagi peneliti mengenai ragam respon ibu yang mengasuh anak dengan GSA semenjak pertama kali didiagnosis hingga anak tumbuh dengan kemajuan perkembangannya. Dengan pendekatan fenomenologi, tujuan penelitian ini adalah mengeksplorasi:1) pengaruh pengalaman memiliki anak dengan GSA terhadap kehidupan Ibu; 2) faktor-faktor yang membuat Ibu mampu bertahan selama mengasuh anak dengan GSA; dan 3) dinamika Ibu selama mengasuh anak dengan GSA. 


\section{Metode Penelitian}

Penelitian ini menggunakan analisis fenomenologi interpretatif. Responden berjumlah lima orang, yang diperoleh berdasarkan kriteria utama, yaitu ibu yang memiliki anak telah terdiagnosa mengalami GSA oleh dokter atau psikolog dengan menggunakan Childhood Autism Rating Scale; merupakan orang tua kandung dari anak; merawat anaknya secara langsung dan tidak menitipkannya di asrama khusus anak dengan GSA. Penelitian ini dilakukan selama dua bulan di Pusat Layanan Autis, Yogyakarta. Kelima responden telah menyatakan kesediaan untuk terlibat dalam penelitian ini dan melengkapi informed consent sebagai tanda kesediaannya berpartisipasi secara sukarela. Prosedur pengambilan data sudah dievaluasi oleh Komite Etika Penelitian Fakutas Psikologi UGM.

Pengalaman ibu selama mengasuh anak dengan GSA dikumpulkan dengan teknik wawancara mendalam. Wawancara dalam penelitian ini dilakukan dengan mengajukan pertanyaan terbuka sehingga peneliti dapat mengembangkan pertanyaan lanjutan berdasarkan jawaban responden. Peneliti menggunakan alat bantu untuk merekam proses wawancara dengan izin dari responden. Hasil wawancara ditranskip untuk memudahkan peneliti dalam proses analisis data.

Beberapa proses inti penelitian fenomenologi dilakukan di dalam penelitian ini, yaitu: epoche, phenomenological reduction, imaginative variation, dan synthesis (Moustakas, 1994). Pertama, epoche, yaitu peneliti menangguhkan dan menyingkirkan segala bentuk opini, prasangka, dan bias atas sesuatu yang ditelitinya. Kedua, phenomenological reduction, tahap ini terbagi menjadi dua bagian, yaitu bracketting dan horizonalizing. Bracketting adalah menempatkan fokus penelitian ke dalam bracket atau keranjang, artinya hal-hal lain yang tidak sesuai dengan penelitian dikesampingkan sehingga seluruh proses penelitian berasal dari topik dan pertanyaan penelitian. Horizonalizing adalah menempatkan semua pernyataan atau data ke dalam posisi yang sama. Pernyataan atau data tersebut kemudian hanya dipilih yang relevan saja dengan topik penelitian. Data yang sifatnya repetitif dan tumpang tindih selanjutnya disingkirkan, sehingga yang tersisa hanya horizons atau arti tekstural dan unsur pembentuk dari fenomena yang sesuai dengan topik penelitian. Ketiga, imaginative variation, yaitu proses untuk mencapai deskripsi tekstural dari pengalaman, mencari tahu faktor-faktor yang mendasar apa saja yang memengaruhi pengalaman. Proses tersebut berkaitan dengan bagaimana pengalaman tentang phenomenon (fenomena yang diteliti) menjadi seperti sekarang ini. Keempat, synthesis, yaitu mengintegrasikan deskripsi tekstural dan struktural menjadi satu pernyataan yang esensial, inti pengalaman dari fenomena secara keseluruhan. Kredibilitas hasil dalam penelitian ini menggunakan member checking (Moustakas, 1994).

\section{Hasil dan Pembahasan}

Secara garis besar, deskripsi fenomenologis dari responden dapat dikelompokkan ke dalam enam tema yang dialami secara berurutan, yaitu: 
Tema 1 : Bertahan dalam kondisi sulit dan menekan.

Sikap hidup menguatkan diri sendiri seperti tidak mengeluh, gigih, tidak berputus asa, sikap pantang menyerah dari segala permasalahan yang datang silih berganti. Permasalahan dapat berasal dari anak dengan GSA sendiri, seperti permasalahan perilaku, emosi negatif dan keterbatasan dalam berkomunikasi, maupun permasalahan yang datangnya tidak berhubungan langsung dengan anak, seperti biaya pengasuhan yang cukup besar, dan adanya stigma negatif dari masyarakat akan kondisi anak. Permasalahan-permasalahan tersebut memunculkan emosi negatif seperti sedih, menyalahkan diri dan cemas. Namun, adanya keyakinan bahwa ibu adalah wanita yang tangguh dan kemampuan mengontrol diri baik, membuat ibu mampu untuk segera bangkit dan berkomitmen terhadap dirinya sendiri untuk kuat dan berpikir positif atas kondisi yang sulit dan menekan.

Empat sub tema muncul dalam cakupan tema "bertahan dalam kondisi sulit dan menekan", yaitu:

a. Perjuangan tiada henti, merupakan usaha yang dilakukan secara terus menerus dengan tujuan untuk mengoptimalkan tumbuh kembang anak dengan GSA selama kehidupan anak. Sebagaimana yang dikemukakan oleh salah satu partisipan berikut ini:

"Anak saya sekarang sudah bisa buang air besar sendiri, makan, dan mandi sendiri, awalnya sulit mengajarkannya, namun secara konsisten dan pantang menyerah saya terus mengajarinya, akhirnya anak saya sekarang sudah bisa mandiri. Sekarang yang saya lakukan adalah bagaimana supaya anak saya bisa mandiri dalam hal pekerjaan, agar dari pekerjaannya itu dia mampu menghasilkan uang dan dapat memenuhi kebutuhannya sendiri kelak di usianya dewasa” (partisipan B).

b. Bertanggung jawab, kesadaran ibu dalam menjalankan perannya sebagai seorang ibu sekaligus istri, yaitu berupaya memberikan pengasuhan yang terbaik buat keluarga. Seorang partisipan mengemukakan:

“....dukungan ini minim sekali untuk saya..tapi kalau saya bisa survive itu ya berjalan begitu saja...mungkin karena saya sudah bisa menerima kekurangan anak saya...jadi ya saya survive aja...karena ini memang tanggung jawab saya..ini memang amanah dari Tuhan yang dititipkan ke saya...ini kewajiban saya... saya merasakan sekarang sudah lebih tenang...kalau dulu awalnya saya sering menangis...ada perasaan marah..marah dengan diri sendiri dan marah ke Tuhan juga...menyesal..menyalahkan diri.. "(partisipan C).

c. Bangkit, yaitu kemampuan untuk kembali lagi ke dalam kondisi normal (adanya emosi positif) setelah mengalami suatu kondisi keterpurukan (ibu lebih banyak merasakan emosi negatif). Beberapa partisipan menyampaikan sub tema bangkit diantaranya partisipan A dan B.

“....kalau saya selalu sedih..selalu menyesal....larut dalam kesedihan itu..nanti saya tidak bisa berbuat sesuatu untuk anak..jadi memang saya harus bangkit... (partisipan A). 
“.... saya tidak boleh tenggelam... tidak boleh terlarut dengan kesedihan..karena kalau saya selalu tenggelam kesedihan...nanti saya gak bisa memperjuangkan haknya anak...karena anak punya hak untuk mendapatkan pengasuhan..untuk mendapatkan pendidikan..." (partisipan B).

d. Kontrol, ibu mampu meregulasi dirinya atas kemunculan berbagai sumber stres.Kemampuan mengontrol diri tatkala emosi dan pikiran negatif muncul, misalnya perasaan menyalahkan diri sendiri atas kondisi keterbatasan yang dialami anak, perasaan cemas akan masa depan anak. Partisipan mengungkapkan:

"Tidak mudah bagi saya untuk langsung menerima kondisi anak, perlu waktu sekitar tujuh tahun saya baru bener-bener membuka diri, selama tujuh tahun itu juga saya sering dihantui perasaan bersalah karena dulunya pada saat hamil A, saya kurang perhatian dengan kehamilan saya, begitu juga setelah melahirkan A, saya tidak memberikan asi eksklusif dan A lebih banyak dirawat baby sitter, saya adalah wanita karir yang sangat sibuk mengelola perusahaan...akhirnya saya menyadari semua itu gak ada artinya...saya mulai bangkit dan melawan perasaan bersalah ketika muncul...dengan cara banyakin aktivitas dan tetap berpikir positif"' (partisipan B).

Tema 2 : Dukungan selama penyesuaian

Dukungan selama penyesuaian diperoleh dari dukungan formal (seperti sekolah, pusat layanan autis, rumah sakit) dan dukungan informal (seperti pasangan, keluarga, komunitas dan dukungan dari para profesional, yaitu dokter, psikolog, guru, terapis). Dukungan dari teman sesama ibu dan komunitas dirasa sangat berperan dalam mengasuh anak, misalnya dari sesama anggota komunitas yang dinamakan FORKOMPAK (Forum Komunikasi Orang Tua dan Masyarakat Peduli Autis) di Yogyakarta, yang berdiri pada tahun 2015 dan sekarang sudah terdapat kurang lebih 60 anggota orang tua yang memiliki anak dengan GSA. Seorang partisipan mengemukakan:

"Peran suami yang sangat dominan dalam menguatkan saya, lalu dengan saling berbagi bersama orang tua di FORKOMPAK ini, saya merasa tidak sendirian dalam mengasuh anak kami yang unik ini"'(partisipan C).

Tema 3 : Pengetahuan dan informasi terkait pengasuhan anak.

Bagi responden, dengan terus menggali informasi dan pengetahuan terkait kondisi anak dan pengasuhan yang tepat kepada anak, akan membuat ibu semakin kuat. Terdapat dua sub tema yang berkaitan dengan pengetahuan atau informasi terkait pengasuhan anak.

a. Belajar, adalah proses ibu mencari informasi terkait kondisi anak dengan GSA yang menjadi salah satu faktor penting dalam penerimaan orang tua terhadap kondisi anaknya. Kelima responden mengemukakan bahwa mengasuh anak dengan GSA adalah proses belajar yang terjadi sepanjang hidup.

"Ketika saya terus membaca....lalu mencari informasi dan rajin berkonsultasi dengan dokter dan psikolog....saya semakin menyadari betapa minimnya 
pengetahuan saya....dan ini semakin membukakan diri saya untuk menerima anak saya dan memberikan pengasuhan yang lebih baik lagi'"(partisipan D).

b. Peran pola asuh orang tua, yaitu peran pengasuhan orang tua yang ibu dapatkan sejak kecil sangat memengaruhi ibu untuk mengasuh anaknya sekarang. Seorang partisipan mengemukakan:

"Saya berasal dari keluarga besar dan terdiri dari 11 bersaudara, ibu dan bapak saya bekerja sebagai guru lalu sorenya membuat kue untuk dijual di pasar, saya dituntut ibu untuk mampu mandiri dan harus kuat setiap mengatasi masalah, tidak menjadi anak yang cengeng, ketika saya membutuhkan sesuatu maka saya harus berjuang terlebih dahulu untuk mendapatkannya...saya merasakan ini salah satu faktor yang membuat saya sekarang lebih kuat dan bisa bertahan mengasuh anak"(partisipan E).

Tema 4: Peran agama sebagai cara untuk koping

Semua responden dalam penelitian ini beragama Islam. Agama memiliki peran penting dalam memaknai kehidupan yang sulit. Berdasarkan kata-kata kunci yang didapat, maka diperoleh sembilan sub tema yang berkaitan dengan peran agama sebagai cara untuk koping, yaitu: Iman, Husnuzan, Sabar, Ikhlas menerima anak, Ikhtiar, Tawakal, Bersyukur, Pengalaman religius, dan Ibadah.

a. Iman, yaitu keyakinan terhadap Tuhan, yang merupakan dasar keimanan seseorang dalam perannya sebagai makhluk ciptaan Tuhan. Keimanan itu sendiri dapat diartikan dengan percaya. Ibu menyandarkan keyakinannya kepada Sang Pencipta sehingga mempunyai semangat dan kekuatan yang luar biasa di dalam berusaha untuk mencapai harapan agar anaknya mengalami kemajuan dalam tumbuh kembangnya.

"Hal yang utama adalah yakin kepada Allah...jadi ketika kita yakin kepada Allah bahwa Allah itu ada...Allah itu tidak pernah tidur...Allah itu selalu melihat kita..selalu membimbing kita apa yang kita inginkan dengan caranya sendiri yang kita tidak tahu...itu rahasia..jika seseorang tidak memiliki dasar agama yang kuat ..maka seseorang ini akan goyang untuk jalan ke depan...karena tidak ada pondasi yang kuat...(partisipan C).

b. Husnuzan, yaitu berprasangka baik atas pemberian Tuhan kepada ibu, termasuk diberikan anak yang mengalami gangguan perkembangan, diberikan suami dengan karakter yang berbeda dengan ibu, diberikan harta yang cukup bahkan kurang dalam memenuhi kebutuhan anak. Berprasangka baik dengan semua kenikmatan yang Tuhan berikan memiliki makna dan hikmah tersendiri.

"Allah menciptakan umatnya...itu tidak akan pernah salah dan tidak akan pernah kurang...jadi positive thinking dengan pemberian Allah" (partisipan A).

c. Sabar, merupakan usaha ibu dalam mengendalikan diri pada saat kondisi ekstrem (sulit dan menekan). Sabar ini terdiri dari berbagai bentuk perilaku, diantaranya : kebesaran hati dalam menerima kondisi anak, menerima dengan lapang dada, 
mengendalikan emosi, tidak mudah marah, tidak mudah putus asa, bersikap tenang, dan tegar.

“...Salah satu faktor yang menjadikan kita kuat adalah sabar..kenapa sabar?...usaha kita mengendalikan diri pada saat kondisi ekstrem...sabar saat ditimpa ujian.. kembali lagi ke Tuhan ..kalau sudah itu ya pasti kuat...walaupun perasaan ini terkadang naik, bisa bersabar...namun terkadang turun lagi..ya sedih...tapi kembali lagi harus sabar...maka akan kuat lagi...untuk bisa tetap kuat ini kan butuh bahan..ya bahannya itu ikhlas, sabar, ikhtiar, tawakkal..." (partisipan B).

d. Ikhlas menerima anak, adalah menerima kondisi anak dengan memasrahkan jiwa ibu kepada Tuhan. Ikhlas ditunjukkan dengan kemampuan ibu untuk tidak malu dan bersedia menceritakan kondisi anak di depan orang lain, mengasuh anak semata-mata hanya karena Tuhan bukan karena ingin dilihat orang lain, dan keputusan ibu untuk resign dari pekerjaan agar fokus mengasuh anak. Bagi ibu, ikhlas adalah tidak menuntut, tidak mengungkit, tidak menghitung, dan tidak menyakiti.

"Ikhlasnya seorang ibu ditandai dengan tidak malu membawa anak ke tempat umum, ikhlas mengasuh anak hanya karena Tuhan" (partisipan E).

e. Ikhtiar, yaitu usaha yang terus menerus ibu lakukan dengan harapan anak akan mengalami kemajuan dalam perkembangannya, dan yakin usaha yang ibu lakukan tidak akan pernah sia-sia. Dalam hal ini usaha yang dilakukan semata-mata niatnya hanya karena Tuhan.

"Saya tidak perduli dengan anggapan negatif orang lain akan kondisi anak saya..saya tetap jalan aja terus..berusaha memberikan yang terbaik buat anak saya....memasukkan anak ke sekolah autis yang bagus..lalu mencari tempat terapi yang saya juga bisa berkonsultasi baik dengan terapisnya....syukurnya sekarang anak saya sudah banyak mengalami kemajuan tumbuh kembangnya"'(partisipan B).

f. Tawakal, yaitu kepasrahan ibu kepada Tuhan setelah melakukan berbagai usaha. Usaha yang ibu lakukan semata-mata hanya mengharapkan "balasan" dari Tuhan. Hal ini membuat ibu akan merasa lebih tenang dan tidak mendongkol di dalam hati apabila anak belum mengalami kemajuan yang signifikan. Anak yang mengalami GSA memerlukan penanganan ekstra dan bersifat terpadu, artinya diperlukan kerjasama antara orang tua dengan tenaga profesional, ibu juga harus terlibat dan berperan aktif dalam penanganan yang dilakukan agar pengaruhnya terhadap perkembangan anak lebih optimal.

"Saya bersyukur kepada Tuhan...sekarang saya merasa dekat dengan Tuhan..setelah berusaha....biasanya Tuhan akan memberikan yang terbaik buat kita...jadi jangan berpikiran negatif bahwa setiap usaha yang kita lakukan pasti mendapatkan hasil yang maksimal pula" (partisipan A). 
g. Bersyukur, yaitu rasa berterima kasih ibu atas kenikmatan yang Tuhan berikan kepada ibu dan keluarganya, sesulit dan seberat apapun dalam mengasuh anak dengan GSA, sehingga ibu akan lebih tenang ketika mampu memaknai kehadiran anaknya. Hal-hal yang telah Tuhan berikan kepada ibu bukan saja dengan memberikan anak, tapi juga lahir dan bathin ibu menjadi lebih tenang, lebih bahagia, lebih mampu memaknai hidup, dan mampu mengatasi masalah kehidupan.

"Ya Tuhan..terima kasih sudah diberikan kekuatan dan kesabaran dalam mengasuh anak spesial..dengan bersyukur atas hidup maka kita akan lebih bahagia"'(partisipan B).

h. Pengalaman religius, yaitu titik awal ibu mendalami dan menyelami kehadiran Tuhan dalam kehidupannya. Ibu memiliki cerita yang berbeda-beda akan pengalaman religius yang dialaminya. Secara keseluruhan, pengalaman religius ini menjadi faktor utama ibu mampu bertahan dalam mengatasi permasalahan hidup, baik permasalahan terkait pengasuhan anak maupun permasalahan dalam kehidupan rumah tangga. Semakin ibu memohon dan meminta pertolongan hanya kepada Tuhan, semakin ibu menyadari kekuatan dan kehadiran Tuhan dalam kehidupan ibu.

"Hal yang paling memengaruhi hidup saya adalah ketika saya masuk ke lingkungan Sekolah Luar Biasa..melihat beraneka macam manusia dengan kondisinya...dari sini saya belajar yang sangat memengaruhi hidup saya...dulu saya jarang sholat, mengaji, berdoa..tapi ketika saya masuk ke Sekolah Luar Biasa ini..saya merasakan kenikmatan yang luar biasa dari Tuhan..kemudian saya introspeksi diri...dan sekarang saya merasa dekat dengan Tuhan..." (partisipan E).

i. Ibadah, seperti sholat, mengaji, puasa, dan berdoa merupakan peran agama yang paling banyak dijumpai pada ibu-ibu selama mengasuh anak dengan GSA. Keutamaan sholat lima waktu dan ditambah dengan sholat tahajud mampu menguatkan dan memberikan ketentraman, serta menurunkan kecemasan ibu selama mengasuh anak. Terdapat keyakinan pada diri ibu bahwa doa dan permintaan yang dipanjatkannnya kepada Tuhan "Sang Pemberi Kehidupan" akan dikabulkan.

"Beberapa bulan setelah anak didiagnosa autis....saya mengalami masa yang sangat suram..saya gak mau keluar rumah, lebih sering mengurung diri di kamar, saya gak tau apa itu autis, saya hanya sering menyalahkan diri saya atas penyebab anak saya...lalu suami ngajakin saya untuk sholat tahajud, kemudian pas tengah malam beliau membangunkan saya...suami mengatakan supaya saya minta sama Allah..cerita semua sama Allah... apa unek-unek yang dirasakan selama ini...Allah pasti bantu kita...beberapa kali saya lakukan tahajud dan sholat fardhu di awal waktu, kemudian berdoa sama Allah.....saya merasakan lebih tenang dan lebih bisa menerima anak saya" (partisipan E). 
Tema 5 : Kebermaknaan hidup dengan memiliki anak istimewa

Kehadiran anak dimaknai ibu sebagai sesuatu hal yang positif. Pada saat anak terdiagnosa mengalami GSA, muncul emosi-emosi negatif dalam diri ibu, seperti ada perasaan cemas akan masa depan anak sekaligus ada perasaan sedih, namun ibu segera bangkit dan mulai memikirkan rencana-rencana yang harus dipersiapkan dan dilaksanakan guna meningkatkan tumbuh kembang anak. Ada proses reframing disini, artinya pemaknaan kembali akan hadirnya anak, anak yang dulu dianggap sebagai seseorang yang tidak berdaya dan penyebab stres pengasuhan pada ibu, namun sekarang anak dianggap sebagai seseorang yang memberikan ibu kemudahan dan berdampak positif pada diri ibu. Terdapat lima sub tema yang berkaitan dengan kehadiran anak spesial, yaitu :

a. Anak adalah ladang ibadah (penolong), yaitu dalam diri ibu timbul keyakinan bahwa "anak adalah ladang ibadah", dan "anak sebagai penolong/syafaat". Ibu memiliki keyakinan bahwa anak merupakan jalan menuju ke surga . Jika ibu bertanggung jawab menjalankan peran, mengasuh anak dengan rasa kasih sayang, dan memenuhi kebutuhan anak dengan tulus, maka semua yang dilakukan ibu akan diganti oleh Tuhan dengan tempat yang mulia di sisiNya, sehingga anak dimaknai sebagai penolong/syafaat.

"Tuhan memberikan saya anak dengan keunikannya...suatu saat anak ini akan menjadi penolong saya di hari Kiamat...menjadi tabungan saya...karena di hari Akhirat nanti semua perbuatan akan dipertanggungjawabkan...oleh karenanya apa yang telah kita perbuat untuk anak kita akan dinilai sebagai amal kebaikan...."(partisipan C).

b. Tumbuh emosi positif dan motivasi meningkat, yaitu ibu menjadi lebih sabar dan lebih tenang dengan memasrahkan segala permasalahan hidup kepada Tuhan. Hal ini membuat ibu merasakan ketenangan dan lebih bersabar dalam berinteraksi kepada anak.

"Anak ini adalah rezeki dan amanah..saya berpikir positif saja...dengan Tuhan memberikan saya anak spesial seperti ini... saya merasakan perubahan positif dan semakin menyadari peran saya sebagai ibu, menjadi lebih sabar dalam menghadapi permasalahan kehidupan...lebih optimal mengurus anak dan keluarga...lebih mensyukuri hidup"'(partisipan D).

c. Ibu diberikan kemudahan dalam hidup, adalah dengan hadirnya anak, ibu merasa dimudahkan dalam setiap urusannya. Biasanya kemudahan ini hadir ketika ibu telah ikhlas menerima anak, ketika mengasuh anak dengan permasalahannya yang kompleks. Hal ini bukanlah suatu beban bagi ibu sehingga akan terasa lebih ringan dalam mengasuh anak dan kesejahteraan psikologis ibu juga meningkat.

"Saya sudah memasrahkan hidup saya kepada Tuhan....sehingga apapun permasalahan yang datang...saya tetap berusaha dan berdoa agar diberikan kemudahan dalam menyelesaikan persoalan hidup....nah..ternyata benar...Tuhan kasih kemudahan di setiap kesulitan yang saya hadapi.. "(partisipan B). 
d. Anak adalah amanah dari Tuhan, adalah bagi ibu, anak merupakan titipan dari Tuhan. Tuhan memberikan ibu seorang anak yang mengalami GSA karena ibu adalah sosok yang kuat dan mampu. Hal ini didukung dengan keyakinan bahwa Tuhan telah menyiapkan rencana-rencana yang terbaik buat ibu.

"Kehadiran anak ini banyak membawa perubahan pada diri saya...anak ini adalah amanah dan titipan yang Tuhan berikan...berarti harus saya jaga...karena saya yakin saya adalah ibu yang kuat sehingga Tuhan menitipkan anak ini ke saya"(partisipan E).

e. Amalan ibadah semakin meningkat. Salah satu sub tema dari peran agama sebagai koping merupakan keyakinan kepada Tuhan, yaitu merasa semakin dekat kepada Tuhan, dan memohon pertolongan. Ibu mengalami peningkatan amal ibadah, seperti sholat di awal waktu, menambahkan sholat sunnah, senang bersedekah, rutinnya berpuasa, dan intensif mengaji.

"Ketika kita punya masalah....maka serahkan semuanya kepada Tuhan...dan ini akan menimbulkan ketenangan dalam jiwa saya....dengan semakin meningkatnya amal ibadah....maka ini salah satu wujud kebersyukuran kita kepada Tuhan"(partisipan A).

Tema 6 : Optimis

Optimis adalah terdapatnya keyakinan dan harapan baik pada ibu akan usaha yang selama ini dilakukan dalam mengoptimalkan tumbuh kembang anak, dan berharap mendapatkan hasil yang menyenangkan. Sikap optimis dapat membantu meningkatkan kesejahteraan psikologis ibu, sehingga memiliki perasaan yang baik, dan melakukan penyelesaian masalah dengan cara yang logis. Terdapat tiga sub tema yang berkaitan dengan optimis, yaitu:

a. Yakin anak akan mengalami perkembangan yang positif, yaitu ada harapan bahwa anak akan mengalami kemajuan dalam tumbuh kembangnya, sehingga ibu optimis anak memiliki masa depan yang baik. Seorang partisipan mengemukakan:

"Saya hanya berusaha terus meningkatkan kemampuan anak untuk mandiri..kemampuannya untuk bisa merawat dirinya sendiri”(partisipan D).

b. Yakin akan muncul keajaiban dari Tuhan, yaitu keyakinan dan harapan ibu bahwa Tuhan akan selalu memberi pertolongan pada setiap makhlukNya, dengan diiringi usaha dan doa. Sebagaimana yang dikemukan oleh partisipan berikut ini:

"Terkadang ada kejadian di luar pikiran kita ternyata Tuhan bantu..."(partisipan C).

c. Kepercayaan diri, ibu yakin dan percaya akan kemampuan diri, ibu juga yakin bahwa ibu adalah manusia pilihan Tuhan sehingga dititipkan anak dengan kelebihan dan kekurangannya. 
"Saya yakin bisa mewujudkan harapan saya yaitu menciptakan anak saya untuk bisa mandiri.....ya harus dengan daya juang yang tiada hentinya..."(partisipan E).

Hasil yang diperoleh dalam penelitian ini dipaparkan sesuai dengan pertanyaan penelitian, yaitu:

\section{Pengalaman Ibu Memiliki Anak dengan Gangguan Spektrum Autis}

Beberapa informasi diperoleh dari pertanyaan pertama mengenai pengalaman ibu ketika pertama kali anaknya didiagnosis GSA. Pertama, adanya perasaan sangat terkejut, diikuti dengan pikiran bertanya-tanya mengenai berbagai hal terkait kehadiran anaknya yang mengalami GSA, dan tidak pernah menduga akan mendapati anaknya mengalami gangguan perkembangan yang menurut penuturan beberapa profesional tidak dapat disembuhkan. Keterkejutan ini dikemukakan oleh semua responden, bahkan dua dari lima responden tersebut menolak atau tidak begitu saja menerima diagnosis tersebut. Kedua responden mencari profesional lain untuk memperoleh pembanding demi kepastian diagnosis.

Dalam kondisi penolakan ini, ibu mulai menyalahkan diri sendiri, merasa cemas akan nasib anaknya di kemudian hari, malu dengan kondisi anak, sehingga lebih banyak berdiam diri di rumah dan pasrah tidak melakukan upaya yang berarti. Ibu mengaku kondisi pada saat itu merupakan masa yang paling sulit dalam hidupnya, di satu sisi ibu harus memenuhi kebutuhan anak agar tumbuh kembangnya optimal, namun di satu sisi kemunculan emosi negatif dan stigma negatif dari masyarakat membuat ibu semakin terpuruk.

Keterkejutan dan perasaan tidak menentu ini dilalui ibu dengan mencari dan menerima berbagai informasi dari para profesional. Di sisi lain, secara diam-diam, ibu mulai mencari informasi terkait kondisi anak melalui media cetak dan media elektronik. Semakin bertambah informasi yang dimiliki, ibu menjadi lebih tenang dan mulai dapat menerima kondisi anaknya dan mampu mengatasi emosi-emosi negatif seperti sedih, cemas, merasa bersalah, dan bingung.

Disamping dukungan informasi yang membuat ibu menjadi lebih tenang, kelima responden menyatakan mendapat dukungan dari pihak keluarga terdekat, terutama pasangan. Dukungan ini dirasakan menenangkan emosi ibu sehingga lebih berani menatap hidup ke depannya. Dua responden yang sebelumnya lebih banyak berdiam diri di rumah, akhirnya merasa mendapat penguat untuk bersosialisasi dengan masyarakat. Responden yang memulai membuka diri adalah yang mempunyai pengetahuan lebih banyak dan tingkat gangguan yang dialami anak termasuk dalam kategori ringan. Pada saat yang sama dengan proses mencari informasi ini, seluruh responden mengatakan mengadu dan berdoa kepada Sang Pencipta. Hal ini memperlihatkan upaya responden untuk memperkuat jati diri seorang ibu melalui berbagai amalan ibadah, seperti sholat tahajud, puasa, dan rutin mengaji. Kelima responden mengatakan bahwa Sang Pencipta menjadi tempat introspeksi sehingga mereka menjadi sabar, ikhlas, ikhtiar dan tawakal.

Proses ibu anak dengan GSA membutuhkan waktu yang beragam untuk dapat menerima diri anak. Dua responden mengaku butuh waktu hampir dua tahun untuk dapat menerima kenyataan telah dianugerahi anak spesial, hingga akhirnya muncul rasa percaya diri dan mulai berinteraksi dengan lingkungan masyarakat. Dua responden lainnya membutuhkan waktu tidak begitu lama, hanya sekitar tiga sampai enam bulan 
untuk bangkit dari kondisi terpuruk. Data memperlihatkan bahwa demografi responden menjadi salah satu faktor yang berperan dalam penerimaan ibu, seperti tingkat pendidikan dan status kehidupan ekonomi yang cukup mapan, sehingga sarana dan prasarana dalam mengasuh anak dengan GSA terfasilitasi dengan cukup baik. Sementara satu responden menerima kondisi anaknya dalam waktu yang cukup lama, sekitar tujuh tahun, disebabkan kesibukan ibu sebagai wanita karir sehingga kesempatan ibu untuk membangun hubungan dengan anaknya terbatas. Pada saat wawancara dilakukan, ibu mengaku sudah tidak lagi bekerja sehingga memiliki waktu yang lebih banyak untuk berinteraksi dengan anak, seperti misalnya mengantar anak ke sekolah termasuk juga bergabung dengan perkumpulan orang tua yang memiliki anak dengan GSA.

Proses penerimaan diri sebagai ibu dari anak dengan GSA diakhiri dengan kesadaran bahwa mereka adalah individu pilihan Tuhan yang diberi amanah mengasuh anak istimewa, dimana anak merupakan ladang ibadah. Kekecewaan yang dialami ibu akan keterbatasan anak mampu dimaknai ibu sebagai hal istimewa, yang akhirnya membentuk ibu menjadi sosok pribadi yang lebih dewasa, berpikir positif, tangguh, dan optimis.

\section{Faktor-faktor yang memengaruhi ibu bertahan mengasuh anak dengan GSA}

Beberapa faktor dikemukakan oleh responden telah dilakukan untuk mempertahankan diri dan membuat mereka tetap merasakan kebahagiaan dalam mengasuh anak. Usaha berasal dari sumber daya internal dan eksternal. Sumber daya internal meliputi perasaan, pikiran dan tindakan yang bersumber dari dalam diri ibu selama mengasuh anak. Sedangkan sumber daya eksternal meliputi persepsi ibu akan penerimaan dukungan dari luar, sehingga berdampak positif dan mampu menguatkan ibu.

Empat dari lima responden yang telah mengasuh anak dengan GSA lebih dari tujuh tahun mengatakan bahwa kemampuan mengontrol emosi dan pikiran negatif yang muncul merupakan sumber daya internal yang penting. Stres yang dialami ibu terutama disebabkan oleh persepsi ibu mengenai beratnya mengasuh anak dengan GSA. Keempat responden juga secara lebih rinci mengemukakan bahwa kesulitan utama terjadi pada saat menghadapi perilaku maladaptif anak dengan GSA, pada saat yang sama ibu juga harus membagi perhatian dengan anak-anak mereka yang lain. Kondisi sulit ini terjadi pada saat didapati perbedaan pendapat dengan suami yang akhirnya dua diantara lima responden ini berdampak pada perceraian. Keadaan bertambah sulit pada saat ibu mendapat perlakuan kurang hangat dari lingkungan terkait kondisi anak.

Seorang responden yang telah lima belas tahun mengasuh anak dengan GSA mengungkapkan terdapat faktor yang menguatkan, yaitu keyakinan dalam diri bahwa ia dapat mengatasi permasalahan hidup, dan mampu merawat anak agar tumbuh kembangnya menjadi optimal. Keyakinan ini memunculkan sikap pantang menyerah, gigih, tidak mengeluh, dan tegar.

Kelima responden sepakat menyatakan koping religius merupakan sumber daya internal yang berkontribusi penting bagi ibu. Agama memberikan pemikiran positif mengenai kenyataan dan takdir Tuhan sehingga responden pada akhirnya memaknai positif kehadiran anak. Koping religius ini dikemukakan responden dalam bentuk husnuzan, tawakal, sabar, ikhlas, menjalankan sholat, mengaji, berdoa, dan bersyukur.

Sumber daya eksternal yang diterima ibu adalah dukungan sosial. Hasil wawancara dari kelima responden menyatakan bahwa dukungan keluarga dan pasangan 
merupakan yang sangat dibutuhkan ibu selama penyesuaian mengasuh anak. Baik responden yang telah 15 tahun maupun 7 tahun mengasuh anak dengan GSA sepakat mengatakan hal yang sama. Dukungan yang diberikan baik dalam bentuk perhatian maupun informasi seputar pengasuhan anak dengan GSA.

\section{Dinamika ibu dalam mengasuh anak dengan GSA}

Berdasarkan hasil analisis data diperoleh bahwa pada saat awal anak terdiagnosis GSA maka ketersediaan informasi terkait gangguan perkembangan ini menjadi faktor penting bagi ibu. Minimnya pengetahuan dan informasi dapat memposisikan ibu pada situasi yang tidak menentu. Tanpa dukungan sosial, kondisi ini dapat mengakibatkan stres pengasuhan.

Dukungan terbesar yang dirasa meringankan datang dari keluarga, dalam bentuk bantuan berupa meringankan pekerjaan rumah, dukungan informasional berupa saran dan nasihat. Dukungan pasangan yang dirasa meringankan adalah perasaan saling menyayangi dan tidak menyalahkan ibu atas kondisi yang dialami anak. Berdasarkan pengalaman responden, dukungan sosial yang dirasakan ibu membuatnya mampu bangkit dari keterpurukan, membangun kepercayaan diri, dan lebih mampu beradaptasi.

Kelima responden menjelaskan bahwa mereka membangun kompetensi dalam menyesuaikan diri terhadap kondisi stres. Walaupun penyesuaian yang dilakukan berbeda, namun secara keseluruhan memiliki kesamaan, yaitu strategi koping religius. Penggunaan koping religius ini memberikan kebermaknaan positif terhadap diri ibu dan persepsi positif atas kehadiran anak. Ibu yakin kehadiran anak merupakan bentuk kekuasaan Tuhan, salah satu cara Tuhan menyayangi ibu adalah dengan dihadirkannya anak yang spesial karena ibu adalah seseorang yang spesial. Keyakinan ini yang kemudian memberfungsikan diri ibu untuk tetap terus berusaha memberikan yang terbaik atas kebutuhan anak, ibu optimis bahwa anak akan memiliki perkembangan yang lebih baik.

Temuan penelitian ini memberikan gambaran mengenai pengalaman ibu yang mengasuh anak dengan GSA. Pengalaman ini memperlihatkan adanya proses yang dinamis, diawali dengan adanya perasaan yang sulit bagi ibu untuk menerima kenyataan bahwa anak yang dilahirkannya didiagnosis GSA. Pada saat menghadapi ini, umumnya ibu tidak mengetahui dengan jelas apakah itu GSA. Beberapa info yang diperoleh bahwa GSA merupakan gangguan perkembangan yang kompleks, tergolong berat, dan meliputi hampir seluruh aspek perkembangan. Kondisi ibu yang merasa sulit ini sesuai dengan hasil penelitian-penelitian sebelumnya (Gau et al., 2012; McConnell et al., 2014; Ślifirczyk, E, Brayer, \& Maciorkowska, 2013). Dalam kondisi sulit ini, beberapa beban psikologis dirasakan oleh ibu, seperti rasa sedih, marah, kecewa, menyalahkan diri sendiri, dan malu. Hal ini sesuai dengan penelitian sebelumnya (Navot et al., 2015) bahwa ibu mengalami penurunan harga diri, perasaan tidak berdaya, dan depresi. Kuhn dan Carter (2006) juga melaporkan adanya rasa sedih (grief) pada ibu yang memiliki anak GSA menunjukkan adanya penyangkalan, kecemasan, ketakutan, rasa bersalah, kemarahan, kepanikan, keterasingan, kebingungan, ketidakberdayaan, dan rasa malu.

Kondisi yang tidak nyaman ini dialami ibu dalam tempo yang bervariasi, ada yang singkat namun ada juga yang cukup lama. Beberapa faktor memengaruhi cepat atau lambatnya kondisi sulit ini berlalu, dapat dikelompokkan ke dalam faktor internal dan faktor eksternal. Faktor internal dapat diartikan sebagai sumber daya yang berasal dari dalam diri individu, salah satu sumber daya personal yang sering dikaitkan dengan kondisi stres pengasuhan adalah kemampuan melakukan koping. Hal ini didukung 
dengan penelitian Boyd (2002) dan Wang, Michaels, dan Day (2011) membuktikan bahwa strategi koping yang tepat dapat menguatkan orang tua dalam mengasuh anak dengan GSA.

Faktor eksternal adalah persepsi ibu akan keterhubungannya dengan individu lain, meliputi dukungan sosial yang dirasakan (perceived social support). Penelitian secara konsisten menunjukkan bahwa dukungan sosial memegang peranan penting dalam menurunkan stres pengasuhan dan meningkatkan kesejahteraan psikologis ibu (McConnell et al., 2014; Samadi, McKonkey, \& Kelly, 2012). Dukungan sosial yang dirasakan ibu dapat diperoleh melalui dukungan informal yang bersumber dari keluarga, pasangan, komunitas orang tua yang memiliki anak dengan GSA, dan teman, sedangkan dukungan formal bersumber dari sekolah/tempat terapi, pusat layanan autis, rumah sakit. Dukungan informal dan formal ini membuat ibu mampu bertahan dalam kondisi sulit dan menekan. Semakin banyaknya informasi yang diterima terkait dengan kondisi dan penanganan anak dengan GSA, ditambah lagi dengan adanya dukungan dari pasangan dan keluarga akan semakin menguatkan ibu untuk mengasuh anaknya. Dukungan keluarga dan pasangan merupakan dukungan utama bagi ibu, sebab nilai budaya yang menonjol di masyarakat Indonesia adalah kolektivitas yang terdiri dari kebersamaan keluarga besar, dan lebih menekankan koneksi keluarga dan kerjasama. McDermott (2008) menegaskan bahwa orang tua yang memperoleh informasi dan dukungan akan berdampak pada keterampilan serta perasaan yakin dan percaya diri dalam menjalankan tugasnya mengasuh anak. Lee, Anderson, Horowitz, dan August, (2009) menjelaskan bahwa orang tua yang intens mendapatkan dukungan sosial akan menunjukkan sikap pengasuhan yang lebih positif dibandingkan orang tua yang kurang mendapatkan dukungan sosial.

Dukungan sosio emosional dan dukungan informasi yang diterima ibu menjadi salah satu faktor menguatkan sumber daya personal ibu, yaitu kemampuan koping. Koping adalah kemampuan individu dalam mengatasi sumber stres yang hadir. Penggunaan koping yang tepat akan membantu ibu beradaptasi secara positif sehingga ibu mampu bertahan dalam situasi yang menekan. Gray (2006) juga menjelaskan bahwa orang tua melakukan koping dengan mencari informasi tentang GSA, penanganannya serta bagaimana mempertahankan kestabilan emosi dan menyesuaikan diri terhadap pengalaman negatif selama mengasuh anak. Informasi yang dimiliki orang tua adalah salah satu faktor yang memengaruhi penerimaan orang tua (Ogretir \& Ulutas, 2009).

Tidak semua ibu memiliki pengalaman yang sama dalam mengasuh anaknya, terdapat beberapa ibu yang membutuhkan waktu lama untuk dapat bangkit dan menerima kondisi anaknya, namun ada juga ibu yang membutuhkan waktu singkat untuk segera bangkit, menerima kondisi anaknya dan melakukan usaha-usaha untuk mengatasi masalah dengan cara yang tepat melalui strategi koping. Pada ibu yang memiliki anak dengan GSA, strategi koping yang tepat akan membantu mereka beradaptasi secara positif sehingga menjadi lebih kuat dan tidak mudah mengalami stres dalam menjalankan tugasnya sebagai pengasuh anak. Pada setiap ibu berbeda proses dalam menerima anak, dan perlu digarisbawahi bahwa menerima di sini dalam arti bukan hanya sekedar menerima kondisi fisik anak, tetapi juga ditandai dengan keikhlasan dalam menerima anak, ibu memasrahkan segala sesuatu yang Tuhan berikan merupakan pemberianNya yang terbaik. Kemudian ibu juga memaknai perannya dan bertanggung jawab serta ada usaha untuk memberikan pengasuhan yang terbaik demi perkembangan anak menjadi optimal. Ikhlas ditunjukkan dengan kemampuan ibu untuk tidak malu dan bersedia menceritakan kondisi anak di depan orang lain, mengasuh anak 
semata-mata hanya karena Tuhan, bukan karena ingin dilihat orang lain, serta keputusan ibu untuk resign dari pekerjaan agar fokus mengasuh anak. Ikhlas dan berprasangka baik (husnuzan) atas kehendak Tuhan ini hadirnya akan selalu bersamaan dalam menerima anak, ikhlas lebih kepada fungsinya afeksi sedangkan berprasangka baik (husnuzan) lebih berperan fungsi kognitif, kemudian diwujudkan dengan usaha-usaha untuk mengoptimalkan perkembangan anak dan memperjuangkan haknya anak. Secara keseluruhan, ikhlas menerima anak merupakan kunci utama ibu untuk tetap bertahan dalam kondisi sulit dan menekan.

Berdasarkan hasil wawancara mendalam menunjukkan bahwa kelima responden menjelaskan faktor dominan yang memengaruhi ibu dalam menerima anak adalah peran agama sebagai koping. Subandi (2012) dalam penelitiannya tentang peran agama dalam perjalanan gangguan mental psikotik dalam konteks budaya Jawa menemukan bahwa agama berperan penting dalam proses penyembuhan dan pemulihan. Agama dan spiritualitas terbukti berkontribusi secara positif terhadap proses pemulihan dengan berbagai cara yang berbeda, diantaranya adalah agama memberikan dukungan untuk mengatasi (coping) stres, dan agama mampu membuat keluarga dan anggota keluarga sebagai sarana untuk mencari sebuah pemaknaan. Demikian pula dengan penelitian yang dilakukan oleh Corrigan, McCorkle, Schell, dan Kidder (2003) menemukan bahwa keterlibatan agama memiliki hubungan yang positif dengan psychological well-being.

Peran agama sebagai cara ibu untuk koping terlihat dari usaha-usaha yang ibu lakukan semata-mata hanya karena Tuhan, terdapat keyakinan bahwa Tuhan akan memberikan kemuliaan bagi ibu melalui kehadiran anak. Koping religius yang ibu lakukan selama pengasuhan anak seperti ikhlas, husnuzan, sabar, ikhtiar, sholat, berdoa, mengaji, dan tawakal. Bagi ibu, agama dapat membantu ibu memiliki koping positif dalam menghadapi stres pengasuhan, sehingga ibu dapat lebih menerima, memiliki ketangguhan, dan menjalani kehidupan dengan bahagia. Subandi (2012) menjelaskan bahwa terdapat dua macam koping religius yang digunakan, yaitu koping religius yang bersifat kognitif (cognitive religious coping) dan koping religius bersifat perilaku (behavioral religious coping). Berdasarkan teori Subandi (2012) maka dapat dirangkum bahwa koping religius yang bersifat kognitif dalam penelitian ini terkait dengan bagaimana ibu memaknai kehadiran Tuhan dan berprasangka baik atas semua pemberianNya kepada ibu dan keluarga, dan koping religius yang bersifat perilaku terlihat dari usaha ibu dengan melakukan berbagai ritual keagamaan, seperti sholat, berdoa, mengaji dan puasa.

Ibu memaknai kehadiran anak sebagai anugerah dan ladang ibadah ibu untuk menuju tempat yang paling mulia di sisi Tuhan. Ibu merasa sebagai makhluk yang dipercaya oleh Tuhan dengan diberikannya anak beserta kelebihan dan kekurangannya. Pada akhirnya ibu merasa bersyukur atas kehadiran anak karena berdampak positif bagi diri ibu, seperti ibu lebih memaknai hidup, ibu lebih positif dalam menyikapi permasalahan yang ada. Penelitian yang dilakukan oleh Lambert, Fincham, dan Stillman (2011) menunjukkan bahwa peningkatan frekuensi bersyukur dari waktu ke waktu meningkatkan emosi positif dan mencegah peningkatan gejala-gejala depresi. Dababnah dan Parish (2013) menambahkan bahwa iman terhadap Tuhan dapat membantu menghadapi dan menjalani keadaan yang ada. Demikian pula Oprea dan Stan (2012) menyatakan pentingnya harapan dan kepercayaan pada Tuhan untuk menghadapi kondisi anak yang mengalami GSA. Keyakinan terhadap Tuhan akan memunculkan sikap optimis ibu untuk terus mengoptimalkan tumbuh kembang anak, optimis dalam menjalani hidup, optimis untuk terus menggali informasi terkait 
mengasuh anak dengan GSA, sehingga ibu akhirnya lebih percaya diri dalam mengatasi permasalahan hidup yang datang silih berganti.

\section{Simpulan}

Pengalaman ibu dalam mengasuh anak GSA hingga menjadi seseorang yang tangguh merupakan sebuah proses, diawali dengan kemampuan bertahan dalam kondisi sulit dan menekan hingga akhirnya menjadi ibu yang optimis. Faktor utama yang membuat ibu mampu bertahan selama mengasuh anak GSA adalah kemampuan mengontrol diri, peran agama sebagai koping, dan persepsi ibu akan dukungan sosial yang diterimanya. Keyakinan terhadap Tuhan memunculkan sikap optimis ibu untuk terus mengoptimalkan tumbuh kembang anak, lebih percaya diri dalam mengatasi permasalahan-permasalahan hidup yang datang silih berganti.

\section{Daftar Pustaka}

Abidin, R. R. (1995). Parenting stres index-profesional manual. (3rd ed.). Odessa FL: Psychological Assessment Resources.

American Psychiatric Association. (2013). Diagnostic and statistical manual of mental disorders, 5th edition. (DSM-5 TM). Washington, DC: American Psychiatric Association.

Baumrind, D., \& Thompson, R. A. (2002). The ethics of parenting. In M. H. Bornstein (Ed.), Handbook of Parenting Volume 5 Practical Issues in Parenting (Second Ed, Vol. 5, pp. 3-34). New Jersey: Lawrence Erlbaum Associates.

Benson, P. R., \& Kersh, J. (2011). Marital quality and psychological adjustment among mothers of children with ASD: Cross-sectional and longitudinal relationships. Journal of Autism and Developmental Disorders, 41, 1675-1685. http://doi.org/10.1007/s10803-011-1198-9

Biggerstaff, D., \& Thompson, A. R. (2008). Interpretative phenomenological analysis (IPA): A qualitative methodology of choice in healthcare research. Qualitative Research in Psychology, 5(3), 214-224.

Boyd, B. A. (2002). Examining the relationship between stres and lack of social support in mothers of children with autism. Focus on Autism and Other Developmental Disabilities, 17(4), 208-215.

Bromley, J., Hare, D. J., Davison, K., \& Emerson, E. (2004). Mothers supporting children with autistic spectrum disorders. Autism, 8(4), 409-423. http://doi.org/10.1177/1362361304047224

Corrigan, P., McCorkle, B., Schell, B., \& Kidder, K. (2003). Religion and spirituality in the lives of people with serious mental illnes. Community Mental Health Journal, 39(6), 487-499.

Dababnah, S., \& Parish, S. L. (2013). Children and youth services eeview“ At a moment, you could collapse": Raising children with autism in the West Bank. 
Children and Youth Services Review, 35(10), 1670-1678. http://doi.org/10.1016/j.childyouth.2013.07.007

Doussard-Roosevelt, J. A., Joe, C. M., Bazhenova, O. V., \& Porges, S. W. (2003). Mother-child interaction in autistic and nonautistic children: Characteristics of maternal approach behaviors and child social responses. Development and Psychopathology, 15(2), 277-295. http://doi.org/10.1017/S0954579403000154

Gau, S. S., Chou, M., Chiang, H., Lee, J., Wong, C., Chou, W., \& Wu, Y. (2012). Parental adjustment, marital relationship, and family function in families of children with autism. Research in Autism Spectrum Disorders, 6(7), 263-270. http://doi.org/10.1016/j.rasd.2011.05.007

Gray, D. E. (2006). Coping over time: The parents of children with autism. Journal of Intellectual Research, 50(12), 970-976. http://doi.org/10.1111/j.13652788.2006.00933.x

Kuhn, J., \& Carter, A. S. (2006). Maternal self-efficacy and associated parenting cognitions among mothers of children with autism. American Journal of Orthopsychiatry, 76(4), 564-575. http://doi.org/10.1037/0002-9432.76.4.564

Lambert, N., Fincham, F., \& Stillman, T. (2011). Gratitude and depressive symptoms: The role of positive reframing and positive emotion. Journal of Cognition and Emotion, 26(4), 615-633. http://doi.org/10.1080/02699931.2011.595393

Lee, C.-Y., Anderson, J. R., Horowitz, J. L., \& August, G. J. (2009). Family income and parenting: The role of parental depression and social support. Family Relations, 58(4), 417-430. http://doi.org/10.1111/j.1741-3729.2009.00563.x

Li-Ching, L., Harrington, R. A., Louie, B. B., \& Newschaffer, C. J. (2008). Children with autism: Quality of life and parental concerns. Journal of Autism and Developmental Disorders, 38, 1147-1160. http://doi.org/10.1007/s10803-0070491-0

McConnell, D., Savage, A., \& Breitkreuz, R. (2014). Resilience in families raising children with disabilities and behavior problems. Research in Developmental Disabilities, 35(4), 833-848. http://doi.org/10.1016/j.ridd.2014.01.015

McDermott, D. (2008). Developing caring relationship among parents, children, schools, and communities. California: Sage Publications, Inc.

McStay, R. L., Trembath, D., \& Dissanayake, C. (2014). Stres and family quality of life in parents of children with autism spectrum disorder : Parent gender and the double ABCX model. Journal of Autism and Developmental Disorders, 44, 3101-3118. http://doi.org/10.1007/s10803-014-2178-7

Moustakas, C. (1994). Phenomenological research methods. California: Sage Publications, Inc.

Navot, N., Jorgenson, A. G., Stoep, A. Vander, Toth, K., \& Webb, S. J. (2015). Family planning and family vision in mothers after diagnosis of a child with autism spectrum disorder. Autism, 1-11. http://doi.org/10.1177/1362361315602134

Ogretir, A., \& Ulutas, I. (2009). The study of the effects of the mother support education program on the parental acceptance and rejection levels of the Turkish mothers. Humanity and Social Science Journal, 4(1), 12-18. 
Oprea, C., \& Stan, A. (2012). Mothers of autistic children. How do they feel? Procedia - Social and Behavioral Sciences, 46, 4191-4194. http://doi.org/10.1016/j.sbspro.2012.06.224

Pastor-Cerezuela, G., Fernández-andrés, M. I., Tárraga-mínguez, R., \& Navarro-peña, J. M. (2015). Parental stres and ASD : Relationship with autism symptom severity, IQ , and resilience. Focus on Autism and Other Developmental Disabilities, 1-12. http://doi.org/10.1177/1088357615583471

Pruitt, M. M., Willis, K., Timmons, L., \& Ekas, N. V. (2016). The impact of maternal , child , and family characteristics on the daily well-being and parenting experiences of mothers of children with autism spectrum disorder. Autism, 1-13. http://doi.org/10.1177/1362361315620409

Quintero, N., \& McIntyre, L. L. (2010). Sibling adjustment and maternal well-being: An examination of families with and without a child with an autism spectrum disorder. Focus on Autism and Other Developmental Disabilities, 25(1), 37-46. http://doi.org/10.1177/1088357609350367

Rao, P. A., \& Beidel, D. C. (2009). The impact of children with high-functioning autism on parental stres, sibling adjustment, and family functioning. Behavior Modification, 33(4), 437-451. Retrieved from http://online.sagepub.com

Samadi, S., McConkey, R., \& Bunting, B. (2014). Parental wellbeing of Iranian families with children who have developmental disabilities. Research in Developmental Disabilities, 35(7), 1639-1647. http://doi.org/10.1016/j.ridd.2014.04.001

Samadi, S., McKonkey, R., \& Kelly, G. (2012). Enhancing parental well-being and coping through a family-centred short course for Iranian parents of children with an autism spectrum disorder. Autism, 17(1), 27-43. http://doi.org/10.1177/1362361311435156

Selye, H. (1974). Stres without distres. Philadelphia: Lippincott.

Serrata, C. A. (2012). Psychosocial aspects of parenting a child with autism. Journal of Applied Rehabilitation Counseling, 43(4), 29-36.

Ślifirczyk, A., E, K.-K., Brayer, A., \& Maciorkowska, E. (2013). The impact of the disease on functioning of a family with an autistic child. Progress in Health Sciences, 3(2), 122-129.

Subandi. (2012). Agama dalam perjalanan gangguan mental psikotik dalam konteks budaya Jawa. Jurnal Psikologi, 39(2), 167-179. Retrieved from https://repository.ugm.ac.id/id/eprint/97109

Wang, P., Michaels, C. A., \& Day, M. S. (2011). Streses and coping strategies of chinese families with children with autism and other developmental disabilities. Journal of Autism and Developmental Disorders, 41, 783-795. http://doi.org/10.1007/s10803-010-1099-3

Weiss, J. A., Macmullin, J. A., \& Lunsky, Y. (2015). Empowerment and parent gain as mediators and moderators of distres in mothers of children with autism spectrum disorders. Journal of Child and Family Studies, 24, 2038-2045. http://doi.org/10.1007/s10826-014-0004-7

Zablotsky, B., Bradshaw, C. P., \& Stuart, E. A. (2013). The association between mental 
health, stres, and coping supports in mothers of children with autism spectrum disorders. Journal of Autism and Developmental Disorders, 43, 1380-1393. http://doi.org/10.1007/s10803-012-1693-7

Zaidman-Zait, A., Mirenda, P., Duku, E., Szatmari, P., Georgiades, S., Volden, J., ... Thompson, A. (2014). Examination of bidirectional relationships between parent stres and two types of problem behavior in children with autism spectrum disorder. Journal of Autism and Developmental Disorders, 44, 1908-1917. http://doi.org/10.1007/s10803-014-2064-3 